\title{
ANALYTICAL METHODOLOGIES CONCERNING HISTORIC NEIGHBOURHOODS FOR URBAN RENEWAL IN SOUTHERN CHILE. HOW TO UNDERSTAND THE PLACE TO INTERVENE?
}

\author{
Matthias NIEHAUS, Paulina IBIETA (D), Andrés J. PRIETO (D), Emil OSORIO (D), \\ Antonio ZUMELZU (D)* \\ Instituto de Arquitectura y Urbanismo, Universidad Austral de Chile, Valdivia, Chile
}

Received 15 June 2020; accepted 27 January 2021

\begin{abstract}
Historic urban spaces are emplacements that present a particular special interest due to their cultural value and their both urban and architectural pattern. The built environment of cities is composed of a number of variables - anthropic, spatial, morphological, environmental, social, constructive and atmospheric - and all of them must be part of a system that is capable of generating more comfortable and efficient environments. Currently, the work of expert professionals linked to the built environment implies an environmental challenge related to the buildings and their direct harmony with the natural environment; the development of comprehensive plans capable of administering, preserving and protecting historical-heritage constructions in areas susceptible to certain natural disasters; as well as the incorporation of sustainability criteria in urban planning instruments, which is one of the main objectives for regional and state public administrations. This research work intends to propose a comprehensive set of analytical methodologies focused on the morphology of urban blocks, the vitality of the neighbourhood and the functional service life state presented by heritage buildings in order to provide strategies for a proposal for urban regeneration in the case of Barrios Bajos of the city of Valdivia, in southern Chile. This study shows the implications of the proposed methodologies in order to verify their validity and empirically test the application of this type of proposal in one of the historic neighbourhoods of the city of Valdivia, used as a prototype of southern Chile.
\end{abstract}

Keywords: urban renewal, buildings, sustainability, functional service life, historic neighbourhoods.

\section{Introduction}

In emerging Latin American countries exists a lack of standardised urban planning, which is a problem increasingly being placed at the center of twenty-first century development agendas (UN Habitat, 2016). Specially in the Chilean context, Borsdorf and Hidalgo (2010) stated that the urban space has evolved from a compact form to one expanded in the territory and mainly fragmented, undergoing important changes in the last decades and even in historical areas of the cities (Zumelzu \& BarrientosTrinanes, 2019).

In this sense, cities' historic neighbourhoods retain their countries' identity, focused especially on cultural and historical heritage. These urban environments are identified by their traditional character and generally by their particular architectural and urban quality (Doratli et al., 2004). The revitalization process of a historical heritage urban sector implies the integration of a complex set of variables, from the historical legacy to the sense of place, involving contemporary economic, political and social conditions. In this sense, the revitalization of an urban sector with heritage characteristics can be defined, in its simplest form, as a process through which the deterioration and decay of an urban neighbourhood can be addressed and reversed through economic, cultural, social and environmental development (Doratli, 2000). This process is complex and must be approached from different perspectives, including social and economic dimensions, instead of just generating purely physical protection and improvement measures in a long-term perspective (Orueta, 2007). Such a process requires the connectivity of the objectives of the conservation area and the consideration of physical quality, social viability, economic vitality and the broader concern of environmental sustainability (Roberts et al., 2016).

Buissink (1985) defines urban renewal in the physical planning and housing policy field as "the complex of

*Corresponding author. E-mail: antonio.zumelzu@uach.cl 
building activities aimed at restoring the decayed and obsolete physical urban elements and thereby making them functionally sound again according to the standards of the time". According to this, urban renewal includes actions of rehabilitation and restoration, reconstruction and redevelopment. During the last part of the 20th century, there was an evolution of the concept of urban renewal, including not only physical aspects but also social and economic dimensions.

From this perspective, Couch (1990) defines urban renewal as a dynamic process of physical change, or change in use or intensity of use, of the land and buildings, as the effect of the interaction of economic and social forces upon urban areas. This definition includes various social and economic objectives for intervention in decayed urban areas, in which both redevelopment and rehabilitation are actions with high relevance in a neighbourhood-scale approach (Frey, 1999; Frey \& Bagaeen, 2010).

Concerning the Chilean context (Borsdorf et al., 2012), several researchers indicate that intermediate Latin American cities are following a similar pattern of changes to North American and European contexts, mainly in aspects considered the basis of the city: form and function (Ingram \& Carroll, 1981; Bolay \& Rabinovich, 2004; Maturana \& Rojas, 2015). Studies related to urban renewal emphasise the inclusion of various planning issues. Metselaar and Priemus (1992) in its book Urban Renewal Policy in a European Perspective: An International Comparative Analysis refer to the concept as a systematic effort in the field of planning and building as well as of the social, economic, cultural and environmental standards of living, in order to preserve, repair, improve, restructure or clear built-up areas within municipalities. Following this definition, the aim of urban renewal is to explore a broad integration of visions of resolving the multifaceted problems of deprived urban areas to improve their economic, physical, social, cultural and environmental conditions, with multidisciplinary participation and a strategic longterm purpose (Wang et al., 2014; Roberts \& Sykes, 2000; Yung et al., 2016, 2017; Zheng et al., 2014).

\section{Background}

\subsection{Sustainable urban development}

Urban renewal can significantly contribute to sustainable urban development if it follows a sustainable path, since planning both sustainability and urban renewal implicates physical, social, economic and environmental aspects (Zheng et al., 2014).

Research on urban renewal should point to broader perspectives and more objective methodologies for evaluating sustainable urban renewal, since many studies focus only on one or two aspects of sustainability without considering the integration of dimensions. Only by examining the complexity of the dimensional interaction, as well as the evaluation of the past and present situations, can we propose new avenues for sustainable urban renewal
(Zumelzu, 2019). Although studies related to sustainable urban renewal encompass a wide range of topics, Zumelzu (2019) points out four perspectives from which sustainability could be implemented in the field of urban renewal studies: physical, social, economic and environmental.

\subsubsection{Physical perspective}

Urban renewal alters the physical structure of cities, in which urban design plays a key role. In terms of urban design of the built environment, Wang et al. (2014) highlight two main issues: the appearance of cities and the efficiency of urban physical structures. In the U.K., current sustainable development focuses on regeneration projects, generally dominated by the built environment dimension, including aspects such as land use, location and accessibility of services and facilities, infrastructure, buildings, and density (Jenks \& Jones, 2010). Couch (1990) highlights the relevance of the urban renewal concept in facing the continuous expansion and sprawl of cities into their agricultural hinterlands, in which large extensions of urban land are still abandoned and left derelict. Also, considering that people are increasingly relocating to urban areas, the need for renewal of the urban fabric has grown. In this context, resources must be directed toward proper redevelopment of the existing urban fabric or land. This type of resource reuse often reflects thinking along the lines of sustainable development.

\subsubsection{Social perspective}

Within the target of urban renewal, people are the main component of renewal projects, which serve mainly to improve living conditions. Aspects related to population trends, household structure, the elderly, race and communities are important to consider in urban renewal (Lombardi et al., 2011; Talen, 2008). Yung et al. (2016) highlight urban renewal as an important planning strategy to help retrofit the existing conditions of a city at different scales, according to people's diverse needs. These authors show that elderly people consider social and physical activities, community life facilities, services and social networks, emphasizing environments that are clean and pleasant. It is important to consider these criteria to enhance the social well-being of active seniors at public spaces in urban renewal (Yung et al., 2016). Another relevant concern in sustainability of urban renewal projects is heritage conservation in older districts, which can significantly enhance the sense of place, identity and development of a community.

\subsubsection{Economic perspective}

Economic factors of urban renewal include socio-economic status, such as salary, property ownership, social characteristics of households, population, age, , educational achievement, employment, and income level, as well as sources of finance assistance from governments or other organizations. From this approach, Cheshire and Hay (1989) state that due to the historically fluctuating 
economic and social situation from the global scale to the local one, each city is subordinate to change and adaptation. Economic trends directly impact the form and structure of a city, and urban renewal is a key element for this transformation (Cheshire \& Hay, 1989). Urban renewal reduces infrastructure costs through scale and network economies and the re-use of existing resources, while simultaneously raising land values and thereby enabling redevelopment to be viable and reinforce the spatial strategy (Jenks \& Jones, 2010). Regarding issues of transformation, several studies show that urban areas targeted for redevelopment have succeeded in establishing a community for residents in the process. In this context, businesses and services that choose to operate in low-profile brownfield areas due to their history, location and low property values represent part of the existing local social and cultural values (Couch \& Dennemann, 2000).

\subsubsection{Environmental perspective}

Environmental dimensions often related to renewal projects and policies encompass energy consumption, conservation of natural resources, biodiversity and open space, and reduction of pollution and waste. From this approach, most cities worldwide have been designed to cope with different climate conditions but are not adapted to the potential impacts of global warming. For example, de Graaf and van der Brugge (2010) show that urban water managers in the city of Rotterdam developed a new water management strategy combining the renewal of water infrastructure with neighborhood revitalization projects. In the Netherlands, policy objectives have been established to construct more water retention capacity in urban areas in order to adapt to sea level rise caused by climate change (de Graaf \& van der Brugge, 2010). Global environmental problems and the need for a more efficient use of energy and natural resources, as well as to reduce $\mathrm{CO} 2$ emissions, signify the need to adapt urban structures and building fabrication.

\subsection{Revitalization of architectural heritage and its built environment}

Currently, there are more and more strong contributions focused on architectural heritage conservation, which entails direct benefits to the urban environment (Ashworth \& Tunbridge, 2017). Nowadays, international institutions responsible for making these kinds of decisions are more involved in urban development programs, thus recognizing the urgent need to preserve over time the cultural assets that they have in their territory and that are directly related also to the cultural development of their municipalities and regions (Vicente et al., 2015). In the field of construction, it is estimated that currently about $50 \%$ of refurbishments that have been carried out in Europe in the last 20 years have been related in one way or another to the preservation of cities' architectural heritage (European Commission, 2000). However, urban conservation and rehabilitation initiatives are usually too expensive and lack sufficient public funds to regenerate and revitalize their historic neighborhoods through the preservation of their built architectural heritage (Niu et al., 2018).

Some interesting and successful experiences have been the result of either unique efforts or projects from private groups. However, these are small-scale interventions (a group of buildings, a street front), so a comprehensive and sustainable approach is needed to define a global strategic model in the case of a city or a large urban area (Martinović \& Ifko, 2018). In this sense, it is necessary to develop strategic urban planning models that allow one to clearly define the tools that are necessary to develop global and individual approaches to the urban environment, as well as the stock of heritage buildings to be preserved, identifying and evaluating opportunities through a comprehensive assessment of (1) infrastructure, (2) social, (3) technological, (4) constructive, (5) architectural and (6) economic value.

\section{Research aims}

In this research work, an approach was made towards sustainable urban regeneration in a historic neighbourhood in southern Chile. The neighborhood of Barrios Bajos, in the city of Valdivia. The selection of the case study is based on two main criteria. First, the city of Valdivia is an intermediate city in southern Chile, in which there is very little evidence of these processes and today represent a great range of potential and interest from local governements to promote sustainable urban development (Inter-American Development Bank [IDB], 2015; Franchi-Arzola et al., 2018; Zumelzu \& BarrientosTrinanes, 2019). Second, the Barrios Bajos is one of the seven neighborhoods selected within the framework of the National Regeneration Plan for Central Areas (RAC), promoted by the Ministery of Housing and Urbanism (MINVU), to develop sustainable urban renewal strategies, incorporating socio-environmental, heritage and human scale variables (CNDU, 2018).

The management methodologies have focused, on the one hand, on the sustainable conditions of the neighbourhood environment evaluated, and on the other hand, on an analysis of the functional service life of heritage constructions. For this, it is also necessary to incorporate national and international regulatory and specific aspects related to the implementation and management of strategies aimed at both the preventive maintenance of heritage buildings and the sustainability of the direct environment in which they are emplaced

\section{Materials and method}

\subsection{Characterisation of the urban sector under analysis}

The sector of Barrios Bajos in Valdivia constitutes a traditional neighbourhood of the city. With a mainly residential nature, the location coexists with different uses: 
commercial, educational complexes and services, in addition to its industrial past. The boundaries of the neighbourhood are limited by its topographic condition, such as a difference between the city centre and surrounding areas. This sector is bordered on the north by Yerbas Buenas Street (city centre), on the south by Bueras Street, on the east by Aníbal Pinto Avenue and towards the west by General Lagos Street (listed by the Ministry of Housing and Urbanism of Chile) and is less than one hundred meters from the river Valdivia (Figure 1).

It is proposed, then, to study the Guillermo Frick Street as an articulating piece of heritage (ruins), natural (river) and vitality (school) landmarks, whose connection would allow them to be valued and provide a new form of pedestrian mobility to the neighbourhood (Figure 2). The section chosen for analysis corresponds to a node of concentration of activities and vitality in the axis due to the presence of the Prince of Asturias school. This urban intensity coexists with heritage elements identified in the axis. The study proposes to analyse this relationship between heritage and new uses in order to understand how they coexist and how this is manifested in the urban space they share. Figure 2 shows the visual connection from the river edge (ID6 and ID12) to the upper plane of the city (ID7 and ID8) (Figure 2). From ID1 to ID5 and ID9 are the elements chosen for the pedestrian accessibility and vitality analysis. ID1, ID2 and ID3 are the properties chosen from the functional service life examination (Figure 2).

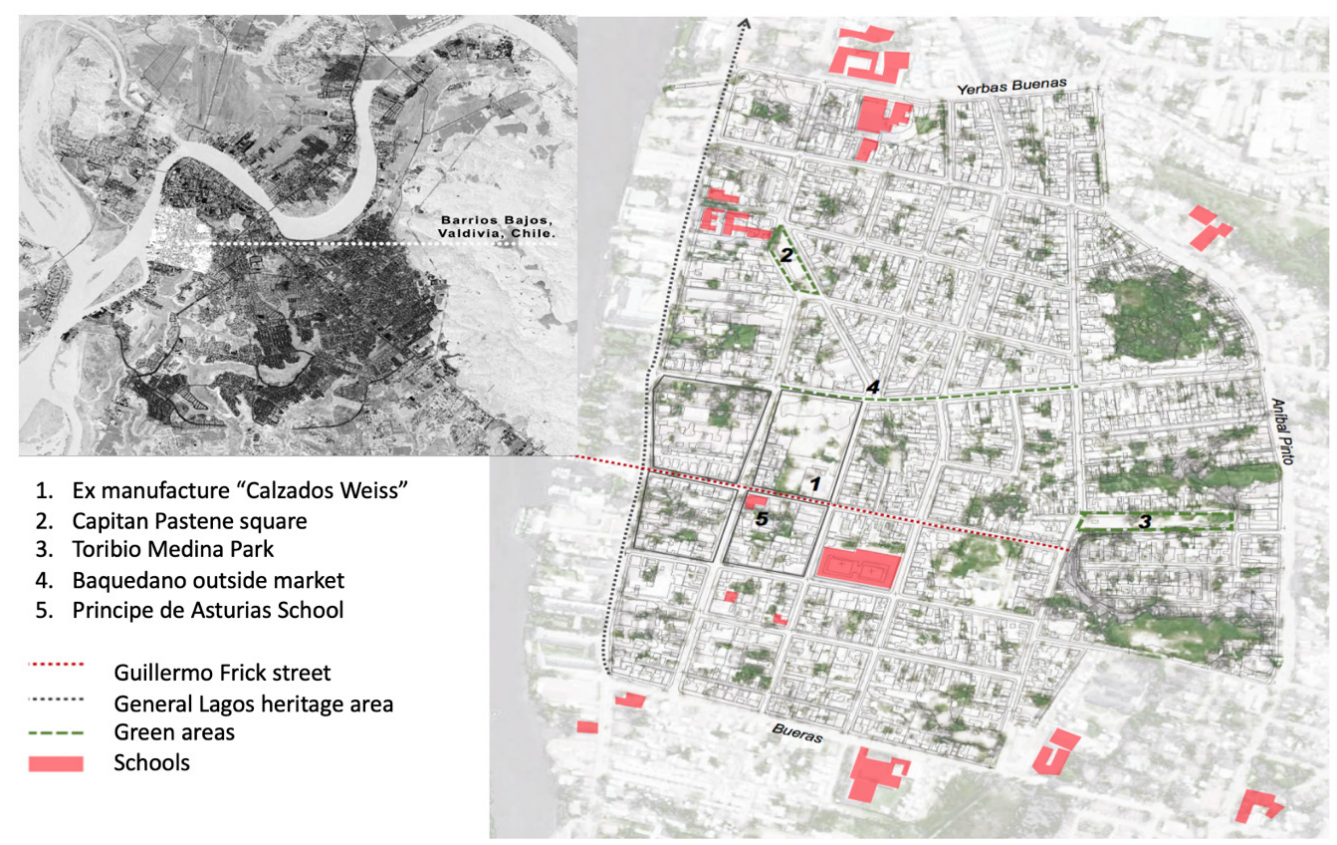

Figure 1. Location of Barrios Bajos sector within the city of Valdivia (left). Location of the case studies in the urban area under study (right)

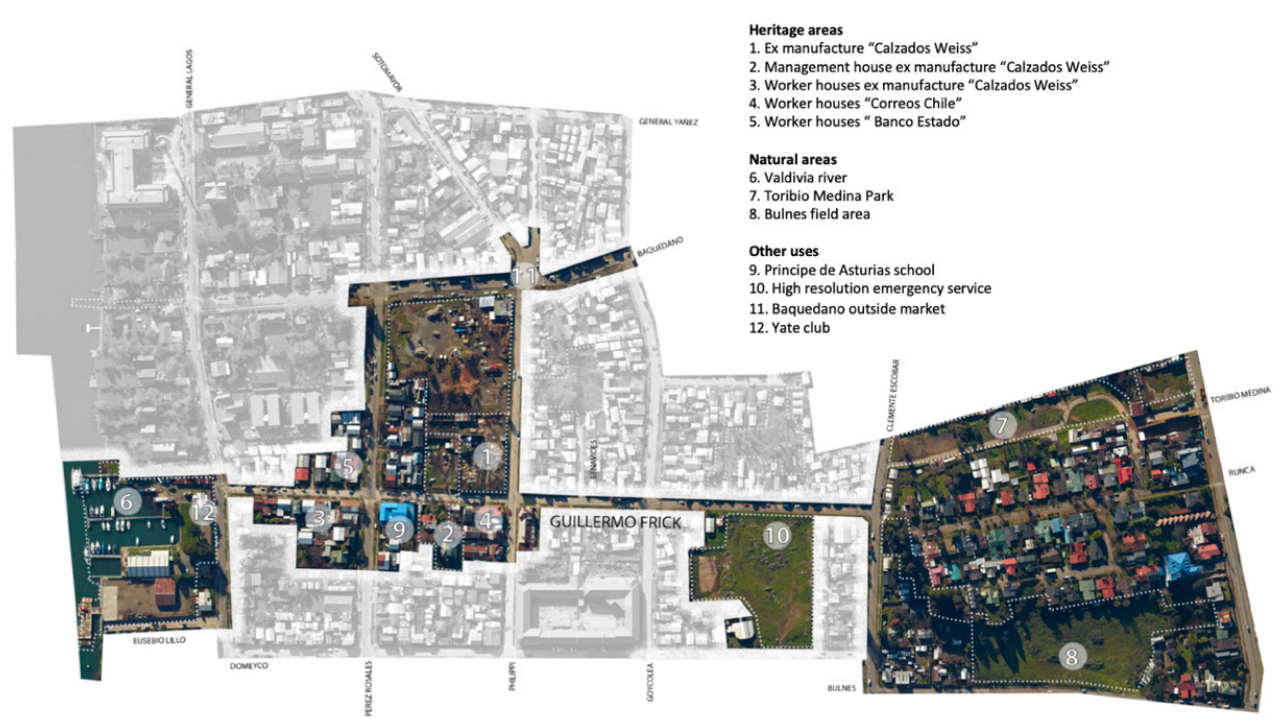

Figure 2. Guillermo Frick Street environment. Urban sector examined 


\subsection{Pedestrian accessibility and quality of the environment (morphology)}

To evaluate pedestrian accessibility, the Morpho method, elaborated by Oliveira (2013), has been used to analyse the scalar patterns of the environment and its influence on pedestrian movement. The method defines the application of two morphological criteria: (1) dimensions of street block frontages: block size assessment involves the division of blocks into groups, defined by the GIS (Geographic Information System) tool of "natural breaks", according to the width of the block façades; and (2) people following method: this method, from space syntax theory (Vaughan, 2001), has been utilised to evaluate two aspects: which environmental factors influence the choice of a movement path, and the distance a person walks between their points of interest and their route choice. By tracking people, the average distance a person walks between their points of interest and their route choice is measured. For route tracking, a radius of 400 metres was defined. During fieldwork, about 25-50 people were followed for a representative sample.

\subsection{Vitality analysis}

To assess the vitality levels of neighborhood nodes, the static snapshot method was applied (Al_Sayed et al., 2014; Vaughan, 2001). This method, from the space syntax theory, allows the observer to register all personal encounters in one static moment when walking around a given area within a period of time. This method is most useful for noting density of use, activities and grouping of activities, rather than for precise recording of numbers or movement rates. It facilitates measuring different usage patterns (static and moving) in convex public spaces (squares, terraces and streets, among others), pedestrian activities (people sitting, walking, standing, interacting or engaging in commercial activities) and parked vehicles. When a round of registration is finished, a map of the collage of human presence and activities in the time span can be generated. Then, the next round of registration follows the same route as the previous round. To make data comparable, the snapshots for different neighborhood nodes were conducted in similar weather conditions. Weekdays and weekends also have very distinct activity patterns. The selection criteria for people followed was mainly people range from 18-65 years old. Also, people were aware of the investigation. Research team show them in field the certifications to do this research, according to the guidelines established at Ethics and Bioethis committee of the Austral University of Chile. Also, the Ministery of Housing and Urbanism was aware of the research according to the agreement cooperation establishments states within the research project. The data recorded are graphically represented and described in maps and charts. To get basic data analysis, the land use patterns in the selected neighborhoods were explored and examined by integrating data from various sources:
- Residential and non-residential (services and facilities, public administration, communal space) land use data georeferenced with GIS in shape file format and polygon geometry (National Institute of Statistics, INE; MINVU, 2019). The information obtained was updated to 2019 through fieldwork analysis.

- Data for net housing density per urban block georeferenced with GIS in shape file format (Laboratory at the Architecture and Urbanism Institute of the Universidad Austral de Chile).

\subsection{Functional service life model based on fuzzy logic}

The theory of fuzzy sets, proposed by Lofti A. Zadeh in 1965 , has been established as a powerful tool when applied in situations with significant levels of associated uncertainty, as in cases where they are intended to model phenomena that occur in the real world, such as the degradation of heritage buildings and their more direct urban contexts. Evaluating the functional service life of buildings and their relationship with environmental degradation agents in the environment is, without a doubt, a complex system of relationships between different factors, which generally requires the opinion of experts in the field.

The Fuzzy Building Service Life extended $\left(F B S L_{2.0}\right)$ expert system (Prieto et al., 2017) consists of a total of 17 input variables (Figure 3), five variables that analyse the intrinsic vulnerability of the constructions (Table 1) and 12 focused on external hazard variables (Table 2): (1) static-structural, (2) atmospheric and (3) anthropic (Macías-Bernal et al., 2014). This set of factors is involved in the degradation of the functionality of buildings, providing a sequenced classification of priority actions for the conservation of the built heritage. These values are hierarchized with each other through a set of inference rules, which generate the relationships between the input variables of the model, in intermediate variables and the output variable. The order of preference generated by the diffuse model depends directly on the output value "construction functionality index or functional service life".

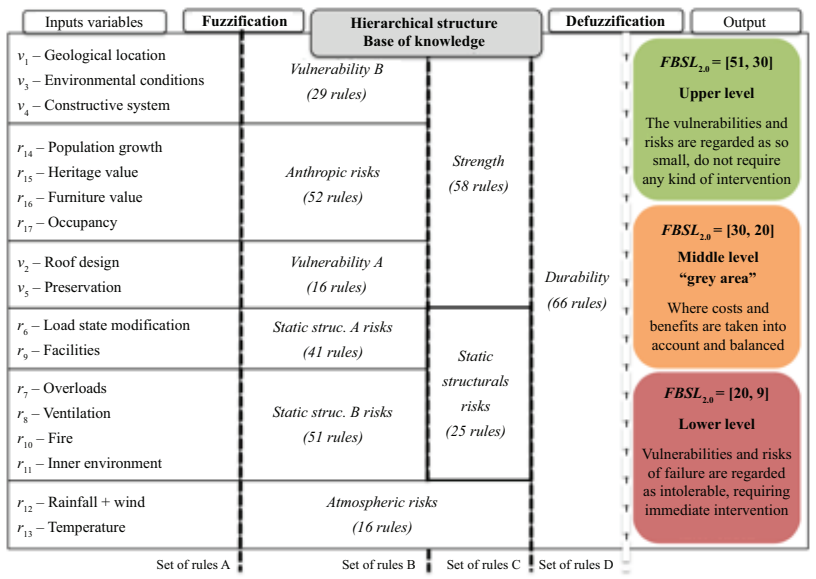

Figure 3. Hierarchical structure of Fuzzy Building Service Life extended $\left(F B S L_{2.0}\right)$ (Prieto et al., 2019) 
The hierarchical structure of the fuzzy model $\left(F B S L_{2.0}\right)$ and the relationships between variables can be checked in Figure 3. The functional service-life model has been previously defined considering a theoretical application in
Valdivia: 51 points is the highest possible serviceability level and 9 points is the lowest possible serviceability level concerning its application in South Chile (Prieto et al., 2019).

Table 1. Vulnerabilities input variables' valuation description on fuzzy model $\left(F B S L_{2.0}\right)$

\begin{tabular}{|c|c|c|c|}
\hline Vulnerabilities & Ids & $\begin{array}{c}\text { Quantitative and } \\
\text { qualitative valuation }\end{array}$ & Description \\
\hline \multirow{2}{*}{ Geological location } & \multirow{2}{*}{$v_{1}$} & 1.0 - favourable & Optimum ground conditions in terms of stability \\
\hline & & 4.0 - unfavourable & Unfavourable ground conditions in terms of stability \\
\hline \multirow{2}{*}{ Roof design } & \multirow{2}{*}{$v_{2}$} & 1.0 - favourable & Fast evacuation of water \\
\hline & & 8.0 - unfavourable & Complex and slow evacuation of water \\
\hline \multirow{2}{*}{ Environmental conditions } & \multirow{2}{*}{$v_{3}$} & 1.0 - favourable & Building without complex constructions around it \\
\hline & & 8.0 - unfavourable & Building located inside of complex constructions around it \\
\hline \multirow{2}{*}{ Constructive system } & \multirow{2}{*}{$v_{4}$} & 1.0 - favourable & Uniform characteristics of constructive system \\
\hline & & 8.0 - unfavourable & Heterogeneous characteristics of constructive system \\
\hline \multirow{2}{*}{ Preservation } & \multirow{2}{*}{$v_{5}$} & 1.0 - favourable & Optimal state of conservation \\
\hline & & 8.0 - unfavourable & Neglected state of conservation \\
\hline
\end{tabular}

Table 2. External hazards input variables' valuation description on fuzzy model $\left(F B S L_{2.0}\right)$

\begin{tabular}{|c|c|c|c|}
\hline Hazards & Ids & $\begin{array}{c}\text { Quantitative } \\
\text { and qualitative } \\
\text { valuation }\end{array}$ & Description \\
\hline \multicolumn{4}{|l|}{ Static-structural } \\
\hline \multirow{2}{*}{ Load state modification } & \multirow{2}{*}{$r_{6}$} & 1.0 - favourable & Apparently modification \\
\hline & & 8.0 - unfavourable & Disorderly modification \\
\hline \multirow{2}{*}{ Live loads } & \multirow{2}{*}{$r_{7}$} & 1.0 - favourable & Live load below than the original level \\
\hline & & 8.0 - unfavourable & Live load higher than the original level \\
\hline \multirow{2}{*}{ Ventilation } & \multirow{2}{*}{$r_{8}$} & 1.0 - favourable & Natural cross-ventilation in all areas \\
\hline & & 8.0 - unfavourable & Natural cross-ventilation nowhere \\
\hline \multirow{2}{*}{ Facilities } & \multirow{2}{*}{$r_{9}$} & 1.0 - favourable & All facilities are in use \\
\hline & & 8.0 - unfavourable & The facilities are not possible to be used \\
\hline \multirow{2}{*}{ Fire } & \multirow{2}{*}{$r_{10}$} & 1.0 - favourable & Low fire load in relation with combustible structure \\
\hline & & 8.0 - unfavourable & High fire load in relation with combustible structure \\
\hline \multirow{2}{*}{ Inner environment } & \multirow{2}{*}{$r_{11}$} & 1.0 - favourable & Maximum level of health, cleanliness and hygiene of the building's spaces \\
\hline & & 8.0 - unfavourable & Low level of health, cleanliness and hygiene of the building's spaces \\
\hline \multicolumn{4}{|l|}{ Atmospheric } \\
\hline \multirow{2}{*}{ Precipitations } & \multirow{2}{*}{$r_{12}$} & 1.0 - favourable & Area with low annual rainfall \\
\hline & & 8.0 - unfavourable & Area with maximum annual rainfall \\
\hline \multirow{2}{*}{ Temperature } & \multirow{2}{*}{$r_{13}$} & 1.0 - favourable & Area with low temperature differences \\
\hline & & 8.0 - unfavourable & Area with maximum temperature differences \\
\hline \multicolumn{4}{|l|}{ Anthropic } \\
\hline \multirow{2}{*}{ Population growth } & \multirow{2}{*}{$r_{14}$} & 1.0 - favourable & Population growth greater than $15 \%$ \\
\hline & & 8.0 - unfavourable & Population growth less than $5 \%$ \\
\hline \multirow{2}{*}{ Heritage value } & \multirow{2}{*}{$r_{15}$} & 1.0 - favourable & Properties with great historical value \\
\hline & & 8.0 - unfavourable & Properties with low historical value \\
\hline \multirow{2}{*}{ Furniture value } & \multirow{2}{*}{$r_{16}$} & 1.0 - favourable & Social, cultural and liturgical appreciation (high value) \\
\hline & & 8.0 - unfavourable & Social, cultural and liturgical appreciation (low value) \\
\hline \multirow{2}{*}{ Occupancy } & \multirow{2}{*}{$r_{17}$} & 1.0 - favourable & High occupancy in the building \\
\hline & & 8.0 - unfavourable & Low occupancy in the building \\
\hline
\end{tabular}


On the one hand, it should be remarked that a total of 15 professionals with an average of 10 years of previous experience worked in the system design stage. For this, the Delphi method was applied in Opina version 3 software (University of Seville, Spain) to obtain and validate the answers of the expert professionals surveyed (Macías-Bernal et al., 2014). On the other hand, the diffuse model has been improved by studying and analysing the ISO 31000: 2009 standard, an international reference in the field of risk management (Prieto et al., 2016). The FBSL 2.0 system is used in the field of vulnerability management, external risks and the functionality of heritage buildings as long as there is constructive homogeneity between the structures and their direct urban environment. These analyses point towards a contribution in the area of preventive maintenance of construction, and also towards the implementation of new paradigms focused on the regeneration of the urban quality of the environment.

\section{Results and discussion}

\subsection{Pedestrian accessibility and quality of the environment. A morphology analysis of Guillermo Frick Street}

The urban area selected corresponds to a node of concentration of activities and vitality along the axis of Guillermo Frick Street. This urban intensity coexists with the main assets identified in the sector under study.

The road network was analysed within a radius of 400 metres from the intersection of Guillermo Frick and Pérez Rosales Streets (Figure 4). It can be seen that the streets parallel to the river (North-South axis) keep the same distance between them, and specifically between Baquedano and Bueras Streets, their paths are straight lines, without breaks or deviations. On the other hand, the streets perpendicular to the river (East-West axis) are more irregular in their arrangement, varying the distance between them and their continuity. This road network generates blocks of regular lengths of $120 \mathrm{~m}$ on the East-West streets, while the North-South blocks vary in their length and do not allow a regular pace for the pedestrian route, with blocks ranging from 100 to 200 metres.

The urban blocks were measured to assess pedestrianization levels. The four blocks studied (A, B, C, D) show that the East-West streets are shorter and more regular, while the North-South blocks tend to be longer and irregular (Table 3). Block B is where the ruin of the former Weiss footwear factory is located. This is the one with the largest dimensions, so its morphology is not the most appropriate to encourage pedestrianization. However, towards Frick Street, the length of the block is $120 \mathrm{~m}$, which allows greater pedestrianization. In this sense, the pedestrianization process of a particular sector of a city can be defined as removing or even restricting number of vehicles from a specific area and devoting it to pedestrian use only. The medium-size cities of southern Chile, such as Valdivia, should begin to devote great attention to the

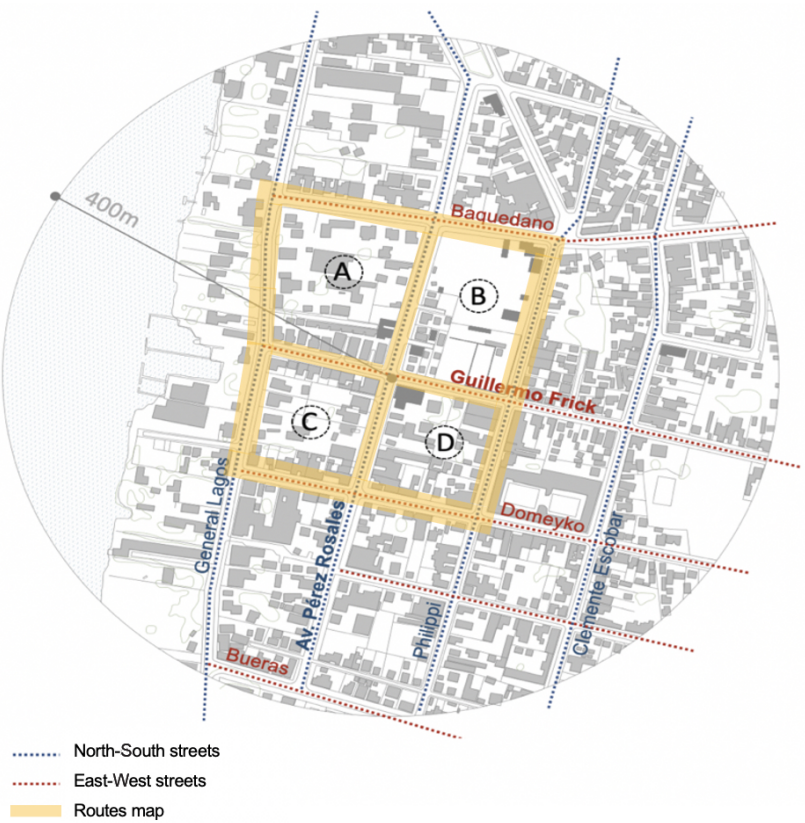

Figure 4. Morphological street analysis around Prince of Asturias school

Table 3. Dimensions of the urban block examined in the study

\begin{tabular}{|c|c|c|c|c|}
\hline $\begin{array}{c}\text { Urban } \\
\text { block }\end{array}$ & $\begin{array}{c}\text { Maximum } \\
(\mathrm{m})\end{array}$ & $\begin{array}{c}\text { Minimum } \\
(\mathrm{m})\end{array}$ & $\begin{array}{c}\text { Difference } \\
(\mathrm{m})\end{array}$ & $\begin{array}{c}\text { Medium } \\
(\mathrm{m})\end{array}$ \\
\hline A & 180.0 & 45.0 & 135.0 & 112.5 \\
\hline B & 190.0 & 120.0 & 70.0 & 155.0 \\
\hline C & 140.0 & 115.0 & 25.0 & 127.5 \\
\hline D & 132.0 & 120.0 & 12.0 & 125.0 \\
\hline
\end{tabular}

social urban aspect and human dimension, including the efficiency of urban places (Nassar et al., 2018).

\subsection{Vitalty analysis}

Static captures were made on two nodes of the Guillermo Frick axis: the corner with Pérez Rosales Street, where the Prince of Asturias school is located, and the corner of Philippi Street, where the ruin is located. A total of four times of day were taken into account concerning the respective measures: (1) $07 \mathrm{~h} 50 \mathrm{am}$, (2) $12 \mathrm{~h} 25 \mathrm{am}$, (3) $04 \mathrm{~h} 25 \mathrm{pm}$ (4) $07 \mathrm{~h} 05 \mathrm{pm}$. These were selected according to the school entrance and exit times, since it is this activity that generates the greatest vitality along the street's axis. By way of registration, photographs and videos were taken to capture the moment. The measurements in the corner of Pérez Rosales and Philippi were made on a Tuesday in order to incorporate the vitality and movement added to the sector by the presence of the fair on Baquedano Street (Figure 5a). The analized streets profiles are included in Figure 5b. Figure 6 represents a schematic analysis of each moment of the day. For this, a rigorous survey of the place was made, identifying the widths of pavements, arborisation, types of façades and their permeability, posts and 
a)
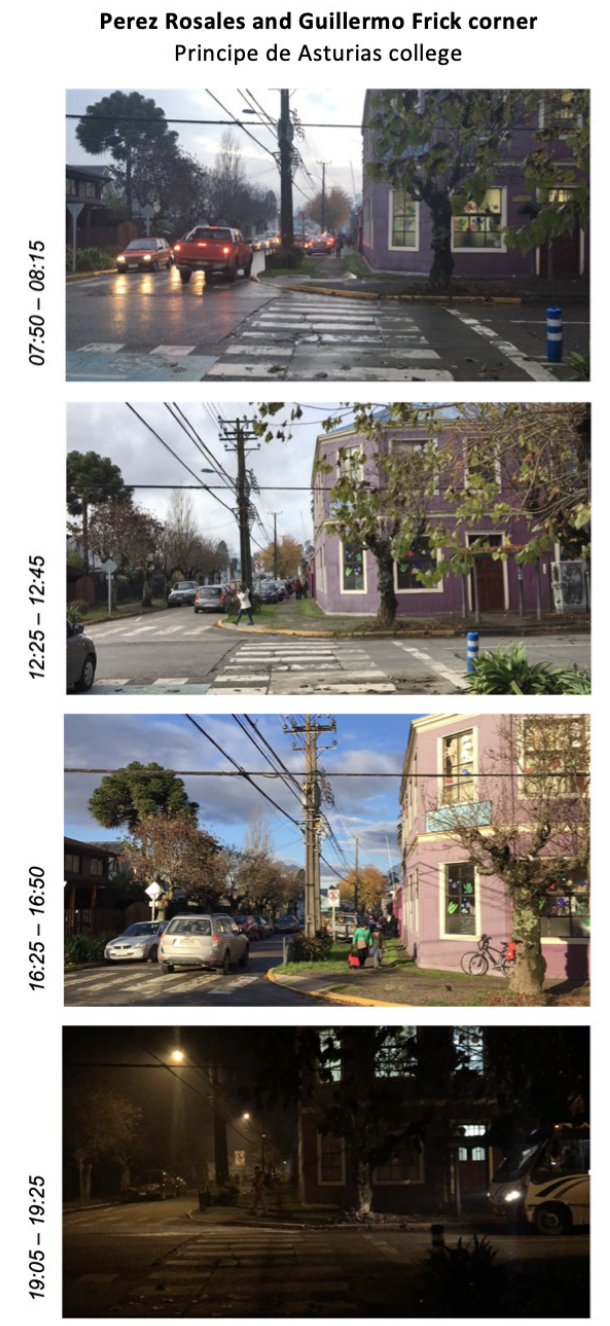

b)
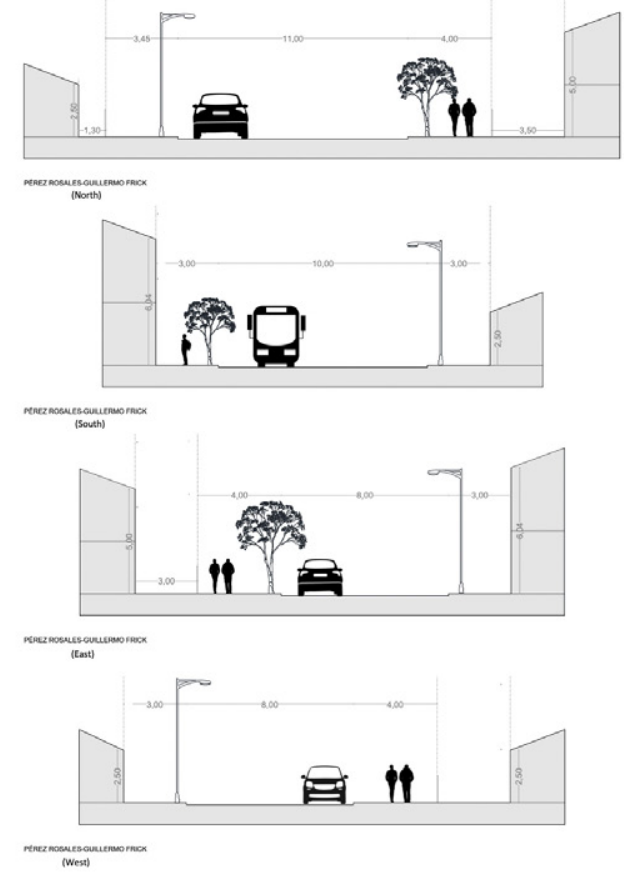

Philippi and Guillermo Frick corner

Ex manufacture "Calzados Weiss"
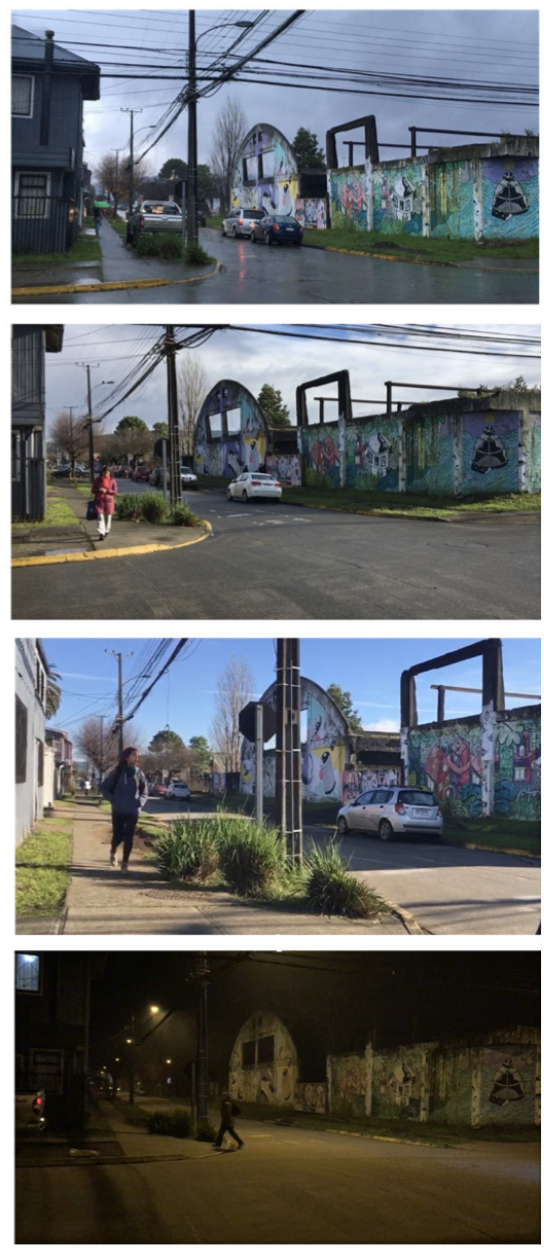

Figure 5. Analysis outcome summary of static captures in Barrios Bajos: a - images of the urban sector under analysis during the four moments considered; $b$ - street profiles of analized corners of Guillermo Frick with Perez Rosales and Philippi streets 


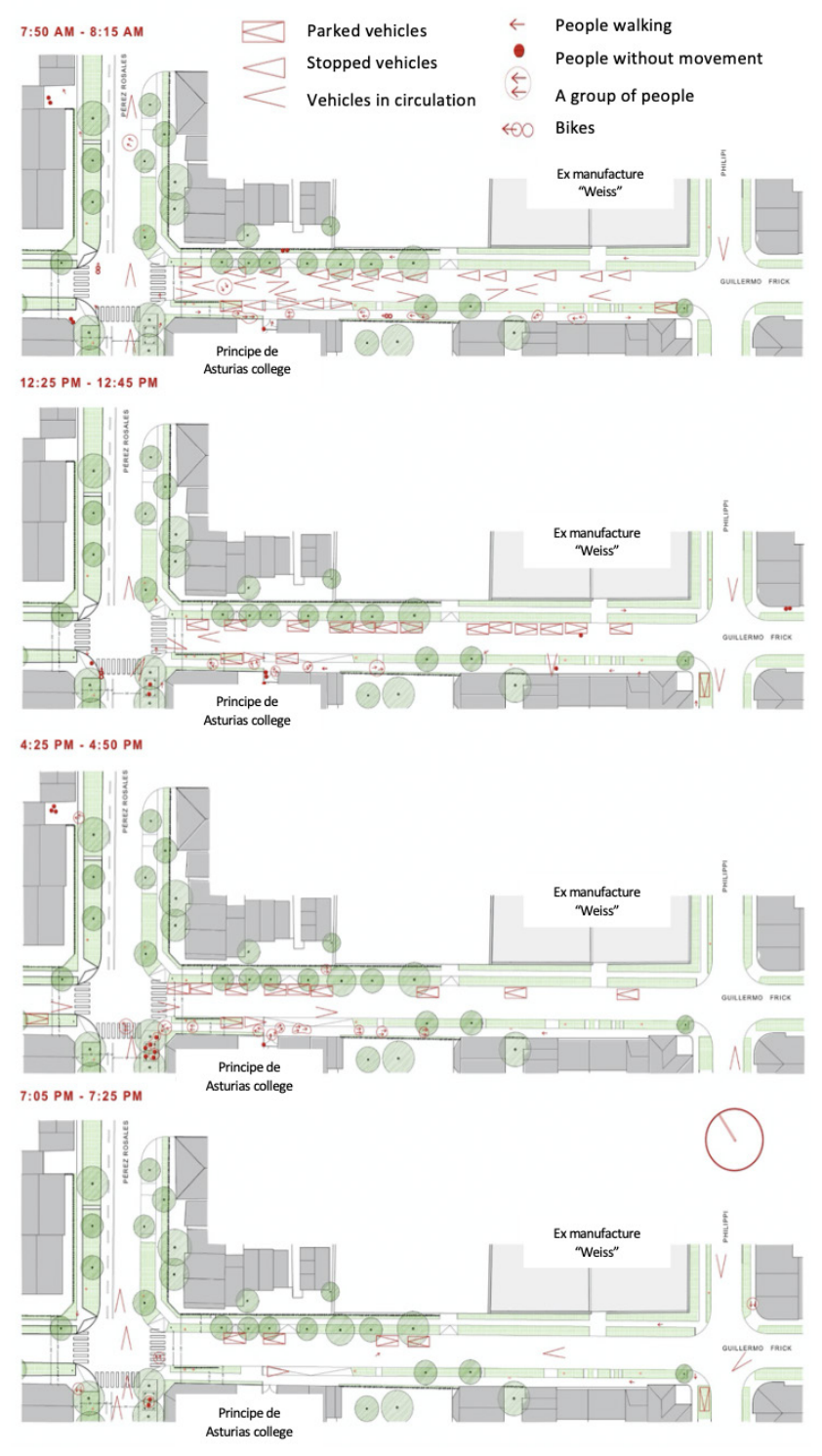

Figure 6. Schematic vitality analysis of Guillermo Frick Street floor recesses. Considering all these elements, it is possible to understand on a very small scale the movements and dynamics of the people in the place.

The school (urban block D; Figure 4) is an element that gives vitality to the sector yet al.o contributes to vehicular congestion and predominance in the urban space. However, sector D corresponds to a neglected structure, which promotes the inverse effect. Most of the pedestrian flow that comes from or goes to the school avoids the sidewalk adjacent to the ruin's façade (Zeng et al., 2018). This is largely due to its secrecy and the low permeability it has towards the street, as well as its cast shadow and the general condition of abandonment in which the ruin is found.

\subsection{Functional service life approach}

Three heritage constructions were selected for the analysis of their functional service life. The constructions are close to the urban sector under study and in the surroundings of the Prince of Asturias school. The buildings identified represent a considerable part of the Guillermo Frick axis, as they are remnants of the industrial past in this sector of the city (Figure 7): (1) the ruins of the former Weiss shoe store; (2) a house formerly belonging to the Heller family, owners of the ex-factory, which today belongs to the Rivera family; and (3) the semi-detached house of the Gomez brothers, who were previously workers at the aforementioned factory. The Fuzzy Building Service Life extended $\left(F B S L_{2.0}\right)$ system was used to determine the values that were raised through the diagnostic sheet showed in Table 4.

\subsubsection{Weiss shoe store}

This construction collapsed with the earthquake of 1960 and therefore is today in a state of ruin. There are only solid elements resistant to the passage of time, mainly of
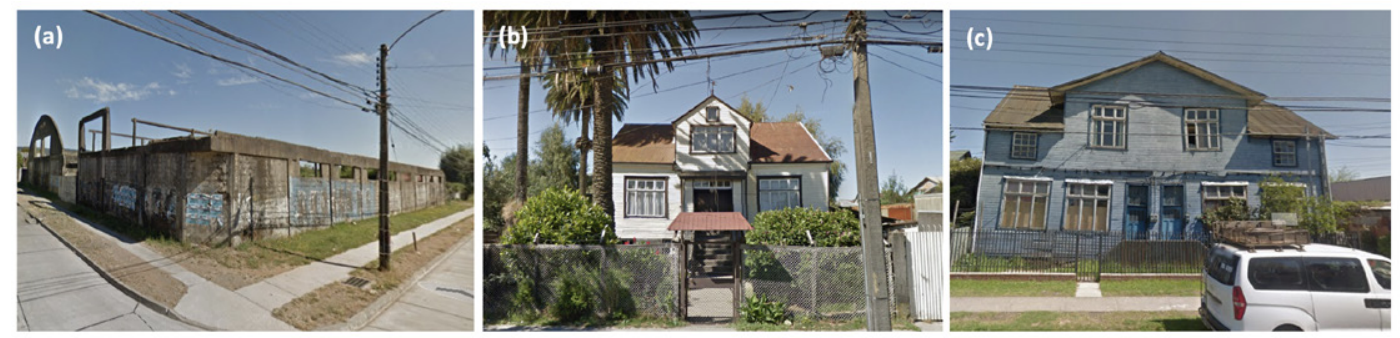

Figure 7. Pictures of the three case studies under analysis: a - Weiss shoe store; b - Heller house; c - Gómez brothers' house

Table 4. Input variables' valuation during the in-situ visual inspection stage and final output of the fuzzy model (functional service life conditions)

\begin{tabular}{|c|c|c|c|c|c|c|c|c|c|c|c|c|c|c|c|c|c|c|c|c|}
\hline Case & \multicolumn{5}{|c|}{ Vulnerability } & \multicolumn{12}{|c|}{ Risks } & & & \\
\hline & $v_{1}$ & $v_{2}$ & $v_{3}$ & $v_{4}$ & $v_{5}$ & $r_{6}$ & $r_{7}$ & $r_{8}$ & $r_{9}$ & $r_{10}$ & $r_{11}$ & $r_{12}$ & $r_{13}$ & $r_{14}$ & $r_{15}$ & $r_{16}$ & $r_{17}$ & $F B S L_{2.0}$ & Condition & $\begin{array}{c}\text { Range } \\
\text { condition }\end{array}$ \\
\hline A & 4.00 & 8.00 & 1.75 & 4.50 & 7.50 & 3.20 & 1.50 & 1.00 & 7.00 & 2.00 & 8.00 & 6.00 & 5.00 & 4.00 & 8.00 & 8.00 & 7.50 & 14.26 & & $(9-20)$ \\
\hline $\mathrm{C}$ & 4.00 & 3.00 & 2.60 & 3.50 & 4.50 & 3.50 & 4.00 & 4.50 & 6.00 & 7.00 & 5.00 & 6.00 & 5.00 & 4.00 & 2.60 & 2.50 & 4.00 & 28.94 & Condition B & $(20-30)$ \\
\hline B & 4.00 & 1.80 & 1.75 & 2.00 & 3.50 & 2.50 & 3.50 & 1.75 & 5.00 & 6.50 & 5.00 & 6.00 & 5.00 & 4.00 & 4.00 & 4.50 & 3.00 & 44.97 & Condition A & $(30-51)$ \\
\hline
\end{tabular}


concrete, which establish the proportions of the set and the measures that the building originally had. Today's use is to collect firewood and construction materials, but mostly the plane has been filled with debris and garbage to cover the plant growth.

The robust state of its structural elements allows its architecture to be abstracted and weather resistant (Figure 7). The space provides functionality, since industrial activities are allowed around firewood and recycling of scrap and debris. The building is operational, although in precarious conditions of abandonment with respect to comfort. Even so, the analysis gives it a graphical representation of its parameterized values, with a score of 14.26 Condition C (low functional service life) (Table 4), considering that it is a building in poor state of conservation, practically destroyed, although still present in the environment where it is located.

This building could maintain its remaining functionality and admits adaptability in the near future. It allows a varied resolution of recovery projects and integration with the public space, mainly for its proportions and historical features. It is therefore a notable figure of the neighbourhood and a characteristic element to be included in either a protection plan or an area of heritage interest (Yoon \& Lee, 2019).

\subsubsection{Heller house}

This construction is architecturally defined by a reinforced concrete and masonry plinth with the ability to store water and separate the house from the water table. This makes the house resilient to flooding and gives it hierarchy with respect to the surrounding buildings, with its setback to the façade line of the other buildings (Figure 7). The central access and symmetrical façade make this house a typical reference of European architecture adapted to the local climate (Saelzer et al., 2019). The recessed hallway generates protected access that was initially glazed and provides a north-faced greenhouse entrance.

The house is built of wood species such as oak, coihue, tepa, laurel raulí and larch, which are native and of great natural value when in good condition. The effective ventilation, the drainage system on the roofs and its elevation above ground level, in addition to its symmetry and adaptable plants, make this building a sustainable element of adaptability in various functionalities.

It has three floors, with a core of spaces that serves the ground floor, bathrooms, kitchen and stairs. It has considerable heights of greater than $2.7 \mathrm{~m}$ indoors and a third floor of private shelter as a mansard. The height and the setback with respect to the street generate a relevant appropriation and an appropriate scale in its context. The analysis using the fuzzy logic methodology values this house with a total score of 44.97 (good functional condition - Condition A) (Table 4), which determines an evaluation in the high range of the scale in terms of functional service life (building without priority for intervention) (Prieto et al., 2019).

\subsubsection{Gómez brothers' house}

This building is located at 1463 Pérez Rosales Street, close to the Frick heritage axis; although not in the corner, it is considered as belonging to the axis. Its current situation is consistent with a state of abandonment, presenting serious structural damage. Today it is used as both a warehouse and a workshop by the owners.

The house has three key concepts to be considered as a building of heritage interest. First, it has a remarkable architecture in terms of adaptability: there are two semidetached houses in one envelope, with symmetrical façades and proportions relevant to the built context $(10 \mathrm{~m}$ high) (Figure 7). A second important value that it presents is the exclusive use of wood when built, now in a state of deterioration, but that represents the neighbourhood's own architecture, standing out from the proportions often reachable in wood. Third, it presents an intangible value of being a collective and adaptable house with two levels and ample space compared to those built today. It is raised 80 $\mathrm{cm}$ above ground level, which allows effective ventilation and adaptation to floods, pondering this building as an example element relevant to sustainable development in the Barrios Bajos sector.

The Gómez brothers' house has an average value score of 28.94 on the scale of fuzzy logic (Table 4), a medium level of functional service life (Condition B). After visual inspection of the building's structural state (Vijay et al., 2019), maintenance actions should be scheduled in order to preserve its functionality over time. Its cover is simple and has no infiltration. The biggest problem lies in its structural damage due to deviation from the vertical axis of the construction, which could be due to seismic effects or terrain emplacement without enough stability. The building should be intervened in a short/medium period of time in order to preserve an acceptable level of functionality (Prieto et al., 2019).

\section{Conclusions and future strategies}

This study is a first approach towards sustainable urban regeneration in a historic neighbourhood in southern Chile. The management methodologies were focused on the environmental, economic, social and physical cultural conditions of the neighbourhood under analysis. Concerning the morphological analysis, some conclusions can be obtained:

- The Guillermo Frick axis has a spatial morphology that promotes pedestrian movement due to its regular blocks measuring approximately 120 metres.

- The street profile measures 14 metres between official lines, which allows a smooth interaction between the paths: people can easily cross at any point from one sidewalk to another without having to wait to reach the corner or to places marked for crossing. This means that the road has a slower speed, the vehicles move with caution along this section of the street, and a superposition of uses between pedestrians, cyclists and vehicles can be seen. 
- A similar situation occurs on the sidewalks: because of the presence of the Prince of Asturias College, many cars are parked or stopped on them. Arborisation plays an important role in preventing or reducing the appropriation of sidewalks by cars, according to Figure 6.

Regarding the vitality analysis, the next conclusions can be achieved:

- In relation to the vitality observed through static capture, it is concluded that the college is an element that gives vitality by promoting social interaction on the street, though it also contributes to vehicular congestion and predominance in the urban space, as it is showed in Figure 6.

- In contrast, the ruin generates the inverse effect, discouraging the vitality that the school injects, as it showed in Figure 5. Much of the pedestrian flow that goes to or from school avoids the sidewalk adjacent to the ruin's façade. This is largely due to its secrecy and the low permeability it has towards the street, as well as its cast shadow and the general condition of abandonment in which it is found.

In terms of the functional service life approach and the heritage preservation value of the construction located in the urban sector examined, the regulations related to Historic Conservation Zones were particularly studied. This study noted the necessity of identifying the protection value of the heritage constructions in the urban area of Guillermo Frick with the objective to consolidate the sector as a Historic Conservation Zone related to its remarkable industrial past.

The condition of heritage intrinsically involves a group of people who feel a root or identify with that heritage; therefore, considering how it is inserted in the city is a way to demonstrate its value and democratize access to heritage. In most cases, the assets are privately owned, and it is very difficult to access them; therefore, a regulation that allows or requires improvements in the urban environment of the property would ensure at least visibility and an effective link with the built environment of the Barrios Bajos sector.

After this approach, some possible future strategies are noted:

- Criteria such as widths of minimum paths, universal accessibility, incorporation of landscaping and equipment, together with new forms of pedestrianization, would allow certain notable spaces such as Barrio Barrios to be transformed into regenerated neighbourhoods with very low public investment.

In this sense, the deteriorated heritage character that is evident in the studied section of the Guillermo Frick axis, added to the morphological conditions that the street has, would allow us to think of a pedestrianization strategy that meets the objectives of valuing the ruin of the former Weiss shoe store and its surroundings as a heritage milestone, as well as restructuring the vitality associated with the dynamics of the place.
This research recommends that this kind of approach be used to enhance stakeholder knowledge concerning urban renewal heritage sectors of Chilean cities. This study can be extended to other kinds of places and can also be adjusted to suit different environmental contexts.

\section{Acknowledgments}

The authors gratefully acknowledge the support of the Institute of Architecture and Urbanism, Faculty de Architecture and Arts, Universidad Austral de Chile, Valdivia, Chile, Ministery of Housing and Urbanism (MINVU) and PNUD Chile, under the project CHL/SDP/095/2020, and Magister en Diseño de Entornos Sostenibles.

\section{Funding}

This paper was funded by the project ANID/FONDECYT No11190554 (Chile).

\section{Conflicts of interest}

The authors declare no conflict of interest.

\section{References}

Al_Sayed, K., Turner, A., Hillier, B., Lida, S., \& Penn, A. (2014). Space syntax methodology (4th ed.). Bartlett School of Architecture, UCL.

Ashworth, G. J., \& Tunbridge, J. E. (2017). Multiple approaches to heritage in urban regeneration: the case of City Gate, Valletta. Journal of Urban Design, 22(4), 494-501. https://doi.org/10.1080/13574809.2015.1133230

Bolay, J. C., \& Rabinovich, A. (2004). Intermediate cities in Latin America risk and opportunities of coherent urban development. Cities, 21(5), 407-421.

https://doi.org/10.1016/j.cities.2004.07.007

Borsdorf, A., \& Hidalgo, R. (2010). From polarization to fragmentation. Recent changes in Latin American urbanization. In P. V. Lindert, \& O. Verkoren (Eds.), Decentralized development in Latin America: Experiences in local governance and local development (pp. 23-34). Springer.

Borsdorf, A., Marchant, C., \& Sánchez, R. (2012). Changes in urbanization processes. Intermediate cities in the Chilean urban system. In D. Rivera (Ed.), Chile: Environmental, political and social issues (pp. 159-173). Nova Publishers.

https://doi.org/10.1007/978-90-481-3739-8_2

Buissink, J. D. (Ed.). (1985). Aspects of urban renewal: report of an enquiry by questionnaire concerning the relation between urban renewal and economic development. International Federation for Housing and Planning.

Cheshire, P., \& Hay, D. (1989). Urban problems in Western Europe: An economic analysis. Routledge.

CNDU. (2018). Política Nacional de Desarrollo Urbano. https:// cndu.gob.cl/wp-content/uploads/2014/10/L4-Politica-Nacional-Urbana.pdf

Couch, C. (1990). Urban renewal: Theory and practice. Macmillan Education. https://doi.org/10.1007/978-1-349-20912-5

Couch, C., \& Dennemann, A. (2000). Urban regeneration and sustainable development in Britain - the example of the Liverpool Ropewalks Partnerships. Cities, 17(2), 137-147. https://doi.org/10.1016/S0264-2751(00)00008-1 
de Graaf, R., \& van der Brugge, R. (2010). Transforming water infrastructure by linking water management and urban renewal in Rotterdam. Technological Forecasting and Social Change, 77(8), 1282-1291.

https://doi.org/10.1016/j.techfore.2010.03.011

Doratli, N. (2000). A model for conservation and revitalization of historic urban quarters in Northern Cyprus [Unpublished Ph. D. thesis]. Eastern Mediterranean University, Gazimagusa, Turkey.

Doratli, N., Hoskara, S. O., \& Fasli, M. (2004). An analytical methodology for revitalization strategies in historic urban quarters: a case study of the Walled City of Nicosia, North Cyprus. Cities, 21(4), 329-348. https://doi.org/10.1016/j.cities.2004.04.009

European Commission. (2000). Research for protection, conservation and enhancement of cultural heritage: opportunities for European enterprises. In Proceedings of the 4th European Commission Conference.

Franchi-Arzola, I., Martin-Vide, J., \& Henríquez, C. (2018). Sustainability assessment in development planning in subnational territories: Regional development strategies in Chile. Sustainability, 10(5), 1398.

https://doi.org/10.3390/su10051398

Frey, H. (1999). Designing the city: towards a more sustainable urban form. Spon Press.

Frey, H., \& Bagaeen, S. (2010). Adapting the city. In M. Jenks, \& C. Jones (Eds.), Dimensions of the sustainable city (pp. 163184). Springer. https://doi.org/10.1007/978-1-4020-8647-2_8

Ingram, G., \& Carroll, A. (1981). The spatial structure of Latin American cities. Journal of Urban Economics, 9(2), 257-273. https://doi.org/10.1016/0094-1190(81)90044-9

Inter-American Development Bank. (2015). Valdivia capital sostenible: plan de acción. ICES, Valdivia, Chile. www.iadb.org

Jenks, M., \& Jones, C. (2010). Dimensions of the sustainable city. Springer.

Lombardi, D. R., Porter, L., Barber, A., \& Rogers, C. D. F. (2011). Conceptualising sustainability in UK urban regeneration: a discursive formation. Urban Studies, 48(2), 273-296. https://doi.org/10.1177/0042098009360690

Macías-Bernal, J. M., Calama-Rodríguez, J. M., \& Chávez-de Diego, M. J. (2014). Modelo de predicción de la vida útil de la edificación patrimonial a partir de la lógica difusa. Informes de la Construcción, 66(533), 006. https://doi.org/10.3989/ic.12.107

Martinović, A., \& Ifko, S. (2018). Industrial heritage as a catalyst for urban regeneration in post-conflict cities Case study: Mostar, Bosnia and Herzegovina. Cities, 74, 259-268.

https://doi.org/10.1016/j.cities.2017.12.013

Maturana, F., \& Rojas, A. (2015). Ciudades intermedias en Chile: Territorios olvidados. RIL Editores.

Metselaar, G., \& Priemus, H. (1992). Urban renewal policy in a European perspective: an international comparative analysis. Delft University Press.

Ministerio de Vivienda y Urbanismo. (2019). Gobierno de Chile. https://www.minvu.cl/

Nassar, U. A. E., El-Samaty, H. M. S., \& El-Zeni, M. M. (2018). Place syntax: an "Optimal area" selection methodology proposed for pedestrianization. Spaces \& Flows: An International Journal of Urban \& Extra Urban Studies, 9(3). https://doi.org/10.18848/2154-8676/CGP/v09i03/29-53

Niu, S., Lau, S. S. Y., Shen, Z., \& Lau, S. S. Y. (2018). Sustainability issues in the industrial heritage adaptive reuse: rethinking culture-led urban regeneration through Chinese case studies. Journal of Housing and the Built Environment, 33(3), 501-518. https://doi.org/10.1007/s10901-018-9614-5

Oliveira, V. (2013). Morpho: A methodology for assessing urban form. Urban Morphology, 17(1), 21-33.

Orueta, F. D. (2007). Madrid: Urban regeneration projects and social mobilization. Cities, 24(3), 183-193.

https://doi.org/10.1016/j.cities.2006.11.004

Prieto, A. J., Macías-Bernal, J. M., Chávez, M. J., \& Alejandre, F. J. (2016). Expert system for predicting buildings service life under ISO 31000 standard. Application in architectural heritage. Journal of Cultural Heritage, 18, 209-218.

https://doi.org/10.1016/j.culher.2015.10.006

Prieto, A. J., Macías-Bernal, J. M., Chávez, M. J., \& Alejandre, F. J. (2017). Fuzzy modeling of the functional service life of architectural heritage buildings. Journal of Performance of Constructed Facilities, 31(5), 04017041. https://doi.org/10.1061/(ASCE)CF.1943-5509.0001021

Prieto, A. J., Vásquez, V., Silva, A., Horn, A., Alejandre, F. J., \& Macías-Bernal, J. M. (2019). Protection value and functional service life of heritage timber buildings. Building Research \& Information, 47(5), 567-584. https://doi.org/10.1080/09613218.2017.1404827

Roberts, P. W., \& Sykes, H. (2000). Urban regeneration: a handbook. Sage Publications Ltd.

Roberts, P., Sykes, H., \& Granger, R. (Eds.). (2016). Urban regeneration. Sage Publications Ltd. https://doi.org/10.4135/9781473921788

Saelzer, G., Gómez, P., \& Ruiz-Tagle, A. (2019, March 26-30). Integral heritage rehabilitation challenges in Southern Chile: The case of wooden cities, Valdivia. In Science and Digital Technology for Cultural Heritage-Interdisciplinary Approach to Diagnosis, Vulnerability, Risk Assessment and Graphic Information Models: Proceedings of the 4th International Congress Science and Technology for the Conservation of Cultural Heritage (TechnoHeritage 2019, p. 236), Sevilla, Spain. CRC Press. https://doi.org/10.1201/9780429345470-44

Talen, E. (2008). Design for diversity: exploring socially mixed neighborhoods. Architectural Press.

UN Habitat. (2016). Urbanization and development: Emerging futures (World Cities Report 2016). UN Habitat.

Vaughan, L. (2001). Space syntax observation manual. University College of London.

Vicente, R., Ferreira, T. M., \& Da Silva, J. R. M. (2015). Supporting urban regeneration and building refurbishment. Strategies for building appraisal and inspection of old building stock in city centres. Journal of Cultural Heritage, 16(1), 1-14. https://doi.org/10.1016/j.culher.2014.03.004

Vijay, P. V., Tulasi Gadde, K., \& GangaRao, H. V. S. (2019). Structural evaluation and rehabilitation of century-old masonry and timber buildings. Journal of Architectural Engineering, 25(2), 05019001.

https://doi.org/10.1061/(ASCE)AE.1943-5568.0000350

Wang, H., Shen, Q., Tang, B., Lu, C., Peng, Y., \& Tang, L. (2014). A framework of decision-making factors and supporting information for facilitating sustainable site planning in urban renewal projects. Cities, 40, 44-55. https://doi.org/10.1016/j.cities.2014.04.005

Yoon, J., \& Lee, J. (2019). Adaptive reuse of apartments as heritage assets in the seoul station urban regeneration area. Sustainability, 11(11), 3124. https://doi.org/10.3390/su11113124

Yung, E. H. K., Zhang, Q., Chan, E. H. W. (2017). Underlying social factors for evaluating heritage conservation in urban renewal districts. Habitat International, 66, 135-148. https://doi.org/10.1016/j.habitatint.2017.06.004 
Yung, E. K., Conejos, S., Chan, E. H. W. (2016). Social needs of the elderly and active aging in public open spaces in urban renewal. Cities, 52, 114-122.

https://doi.org/10.1016/j.cities.2015.11.022

Zadeh, L. (1965). Fuzzy sets. Information and Control, 8(3), 338353. https://doi.org/10.1016/S0019-9958(65)90241-X

Zeng, C., Song, Y., He, Q., \& Shen, F. (2018). Spatially explicit assessment on urban vitality: Case studies in Chicago and Wuhan. Sustainable Cities and Society, 40, 296-306. https://doi.org/10.1016/j.scs.2018.04.021

Zheng, H. W., Shen, Q. G., \& Wang, H. (2014). A review of recent studies on sustainable urban renewal. Habitat International, 41, 272-279. https://doi.org/10.1016/j.habitatint.2013.08.006
Zumelzu, A. (2019). Urban Renewal. In A. Orum (Ed.). The Wiley-Blackwell encyclopedia of urban and regional studies (Vol. 5, pp. 2506-2514). John Wiley \& Sons, Ltd. https://doi.org/10.1002/9781118568446.eurs0391

Zumelzu, A., \& Barrientos-Trinanes, M. (2019). Analysis of the effects of urban form on neighborhood vitality: five cases in Valdivia, Southern Chile. Journal of Housing and the Built Environment, 34(3), 897-925.

https://doi.org/10.1007/s10901-019-09694-8 